\title{
Study of DNA interaction with carbon nanotubes
}

\author{
G.I. Dovbeshko', O.P. Repnytska ${ }^{1}$, E.D. Obraztsova ${ }^{2}$, Ya.V. Shtogun ${ }^{3}$, E.O. Andreev ${ }^{1}$ \\ ${ }^{1}$ Institute of Physics, NASciences of Ukraine, 46 prospect Nauky, 03028 Kiev, Ukraine \\ Phone: +38(044)265 9851; fax: +38(044)265 1589; e-mail: galyna@ukma.kiev.ua \\ ${ }^{2}$ P.N. Lebedev Physics Institute, Russian Academy of Sciences, 53 Leninsky prospect, 117924 Moscow, Russia \\ E-mail: elobr@kapella.gpi.ru \\ ${ }^{3}$ National Taras Shevchenko University of Kiev, Department of Radiophysic, 64 Volodymyrska str., 01033 Kyiv, Ukraine \\ E-mail:slava_ua@mail.univ.kiev.ua
}

\begin{abstract}
Structural characterisation of two different forms of carbon - graphite and singlewalled carbon nanotubes (SWCNT) has been done with Raman and FTIR spectroscopy. Interaction of nucleic acids with graphite powder and SWCNT was studied with Surface Enhanced Infrared Absorption (SEIRA) spectroscopy. Analysis of DNA-SWCNT complex vibration modes has shown that the numerous structural changes in DNA have been connected with appearance of new sugar and bases conformations, changes in phosphate vibrations and could be interpreted as A-B conformation transition and stabilisation of structure in some DNA fragments. Only very slight graphite influence on DNA structure have been registered. We have proposed the model of DNA interaction with SWCNT based on wrapping of nucleic acid molecules around carbon nanotubes. The similar situation seems to occur in chromosome during DNA assembling by histones.
\end{abstract}

Keywords: DNA, Single-Walled Carbon Nanotubes (SWCNT), graphite, Raman, FTIR spectroscopy, Surface Enhanced Infrared Absorption (SEIRA)

Paper received 19.11.02; accepted for publication 18.03.03.

\section{Introduction}

Nowadays a study of carbon nanotubes is of great scientific and applied interest due to their wonderful mechanical and electrical properties [1]. However, due to their not good solubility in any solvents, it is very difficult to isolate one carbon nanotube from another. Some polymers and nucleic acids are known be used for that $[2,3]$ However, the mechanism of the DNA interaction with carbon nanotubes is important for application and fundamental knowledge, however up to date it is not understandable. That is why we decided to perform the experiment enabling to clear up this point.

\section{Method and materials}

To study the DNA interaction with SWCNT, we used Raman and FTIR spectroscopies, namely, one of its new supersensitive method - SEIRA (Surface Enhanced Infrared Absorption) spectroscopy.

The SWCNT was synthesised in the Institute of Physics (RAS, Moscow). Their length was $1-2 \mu \mathrm{m}$, and diameter 1.3-1.5 nm. Aqueous solution of DNA molecules $(0.25 \mathrm{mg}$ DNA $/ 0.5 \mathrm{ml} \mathrm{H} 2 \mathrm{O})$ was heated up to $100^{\circ} \mathrm{C}$ then added $0.5 \mathrm{mg}$ SWCN. Compounds of the solution were mixed, stir and then precipitated onto quartz substrate covered with a gold layer (thickness of the layers was $200 \AA$, roughness was $50 \AA$ ). Spectra were collected in reflectance mode with the reflectance attachment on Bruker IFS-48 instrument in the $380-5300 \mathrm{~cm}^{-1}$ region. Due to using the gold substrate, we observed the effect of SEIRA for nucleic acids [4-6]. KBr pellets have been prepared for registration FTIR transmittance spectra with SWCN and/or graphite. Raman spectra have been registered using NIR - excitation.

\section{Results and discussions}

We studied the vibrational modes of carbon materials of different structures and concluded that SWCNT has more narrow and strong line that graphite (Fig. 1). We registered also band shift at $492 \mathrm{~cm}^{-1}$ to $484 \mathrm{~cm}^{-1}$, at $620 \mathrm{~cm}^{-1}$ to $618 \mathrm{~cm}^{-1}$, at $1129 \mathrm{~cm}^{-1}$ to $1123 \mathrm{~cm}^{-1}$ into low frequency region and $1361 \mathrm{~cm}^{-1}$ to 1363 and 1605 to $1614 \mathrm{~cm}^{-1}$ in high frequency region in SWCNT as compared with graphite. We suppose that the bands at $1361,1363 \mathrm{~cm}^{-1}$ and $1605,1614 \mathrm{~cm}^{-1}$ could be assigned to $\mathrm{C}=\mathrm{C}$ vibrations, other bands - to different other molecular groups, such 


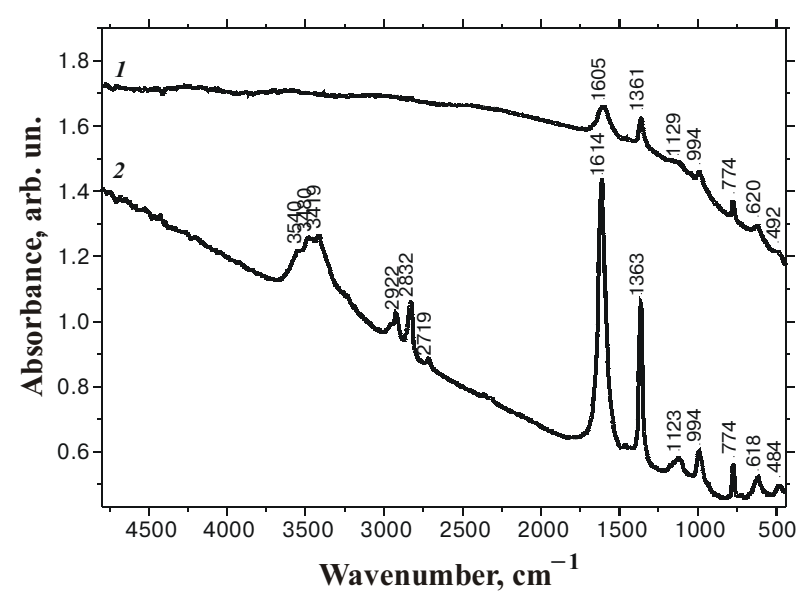

Fig. 1. FTIR spectrum of ultradispersed graphite (curve $I$ ) and carbon nanotubes with graphite surface (curve 2) in the region $440-4800 \mathrm{~cm}^{-1}$.

as C-C, C-O $\left(1129,1123 \mathrm{~cm}^{-1}\right)$, etc. Raman spectra (Fig. 2) showed that graphite have two wide weak bands at 1329 and $1591 \mathrm{~cm}^{-1}$. The SWCNT has very strong peak position at $1593 \mathrm{~cm}^{-1}$ and a shoulder at $1571 \mathrm{~cm}^{-1}$ as well as at $162 \mathrm{~cm}^{-1}$ with shoulders at 147 and $176 \mathrm{~cm}^{-1}$. The band at $162 \mathrm{~cm}^{-1}$ has been identified as the $\mathrm{A}_{1 \mathrm{~g}}$ symmetry radial breathing mode, and the band at $1593 \mathrm{~cm}^{-1}$ has been assigned to an unresolved Raman triplet identified (in armchair symmetry tubes) as tangential carbon displacement modes, $\mathrm{A}_{1 \mathrm{~g}}, \mathrm{E}_{1 \mathrm{~g}}$, and $\mathrm{E}_{2 \mathrm{~g}}$. These three, nearly degenerate, high frequency phonons are related to the graphite $\mathrm{E}_{2 \mathrm{~g}}$ symmetry interlayer mode at $1591 \mathrm{~cm}^{-1}$ [7]. These main SWCNT Raman bands are inhomogeneously broadened due to the tube diameter $(1.3-1.5 \mathrm{~nm})$ distribution.

In our experimental conditions (humidity $\approx 60 \%$ ) we registered the DNA in A conformational state as it was found earlier [5].

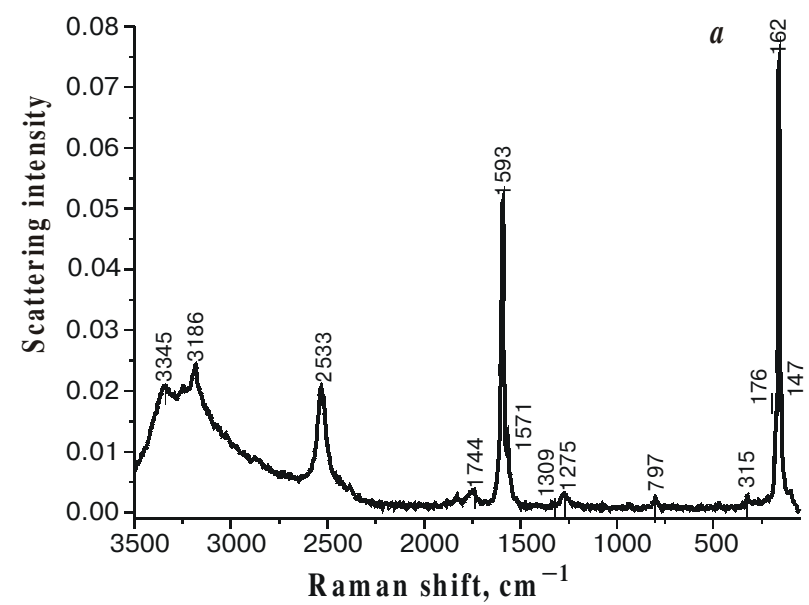

The SWCNT influences the DNA structure more strongly than graphite. In the case of DNA+SWCNT, we obtained the changes of vibration modes of DNA that are the markers of conformational state of DNA $[8,9]$. The changes in marker lines of DNA indicate on DNA interaction with SWCNT. Some transformation of Hbonds in the region of $\mathrm{OH}-, \mathrm{NH}$ - and $\mathrm{CH}$-vibrations was observed (Fig. 3). The increase (about $50 \mathrm{~cm}^{-1}$ ) of the halfwidth of $\mathrm{H}$-bonded $\mathrm{O}-\mathrm{H}$ and $\mathrm{N}-\mathrm{H}$ stretching vibration has been registered for DNA-SWCNT complex. Thus, for reference denaturated DNA and DNA-graphite complex the halfwidth of the OH-NH-CH band equals to $478 \mathrm{~cm}^{-1}$, for DNA-nanotubes complex this parameter equals to $527 \mathrm{~cm}^{-1}$. This halfwidth increase is due to increase of shoulder in the $2950-3200 \mathrm{~cm}^{-1}$ region that indicate to the formation of strong $\mathrm{H}$-bonds of DNA with carbon nanotubes. This could be seen in the Fig. 3 and their difference spectra.

In the region of the bases (Fig. 4), the spectra of DNAgraphite complex and reference denaturated DNA practically has no difference. For DNA-graphite complex a little bit of decrease in the integral intensity (5.27) of the base band have been observed in comparison with reference denatured DNA (5.37). In the case of DNA-SWCNT complex, the essential increase of the absorption of $\mathrm{C}=\mathrm{O}$ molecular groups at $1712,1700,1685 \mathrm{~cm}^{-1}$ and $\mathrm{C}=\mathrm{N}$ at $1608 \mathrm{~cm}^{-1}$ have been registered. This fact could be interpreted as partial manifestation of DNA B-conformation. The latter leads to increase in the integral intensity of the base band to 6.24 for DNA-SWCNT complex. Relative intensity of base vibrations is increased in the spectrum of DNA/SWCNT in comparison with those for reference DNA. All these features testify that in the case of DNASWCNT complex the B-helical DNA structures are restored.

We have registered the low-frequency shift of antisymmetrical $\mathrm{PO}_{2}$-vibration both for DNA-SWCNT and DNA-graphite complexes (Fig. 4). For reference DNA frequency position of antisymmetrical $\mathrm{PO}_{2}$-vibra-

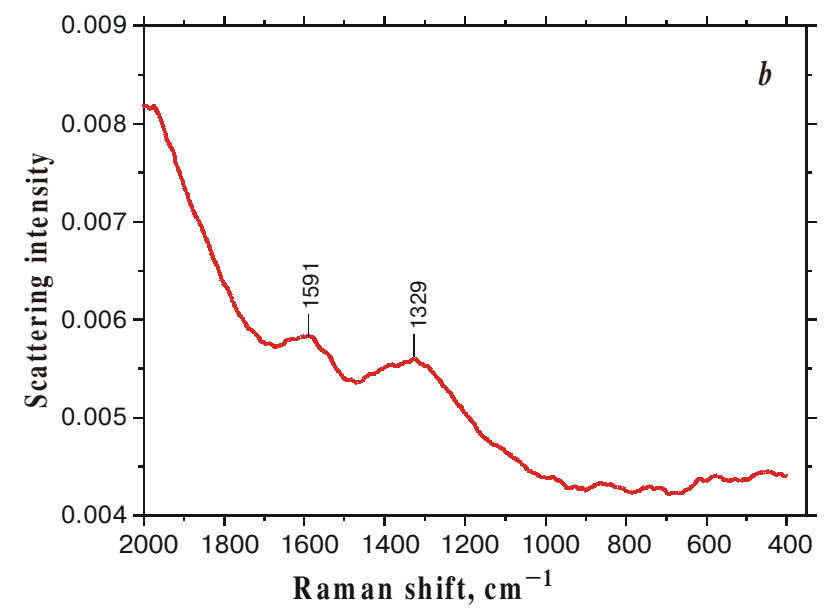

Fig. 2. Raman spectra of carbon nanutubes $(a)$ and graphite $(b)$ obtained with NIR excitation (spectra were registered by Dr. Manfred Westermaer, Frieburg, Germany). 


\section{G.I. Dovbeshko et al.: Study of DNA interaction with carbon nanotubes}

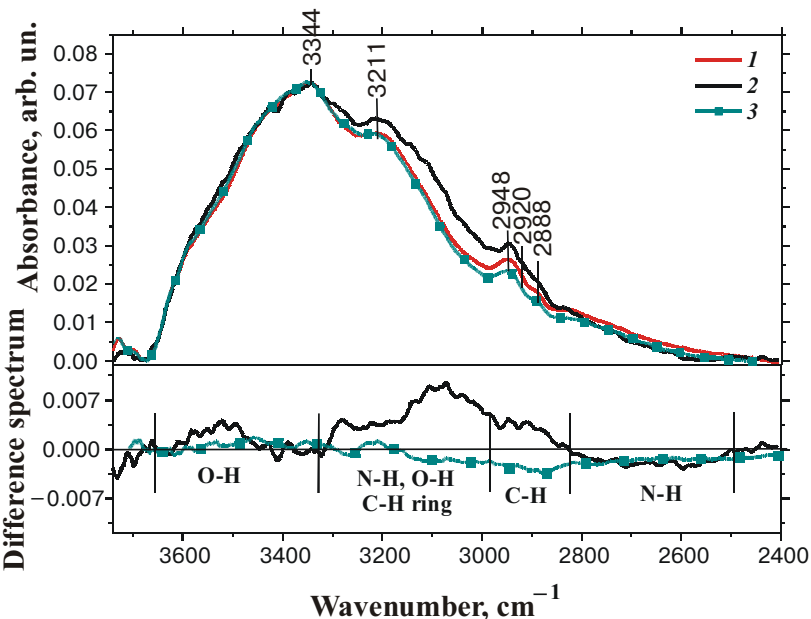

Fig. 3. SEIRA spectrum of denaturated DNA (curve 1), DNA with carbon nanotubes (curve 2) and DNA with ultradispersed graphite (curve 3) on the gold substrate in the region 2400-3800 $\mathrm{cm}^{-1}$. Difference spectrum $=$ DNA with carbon nanotubes or with graphite - denaturated DNA.

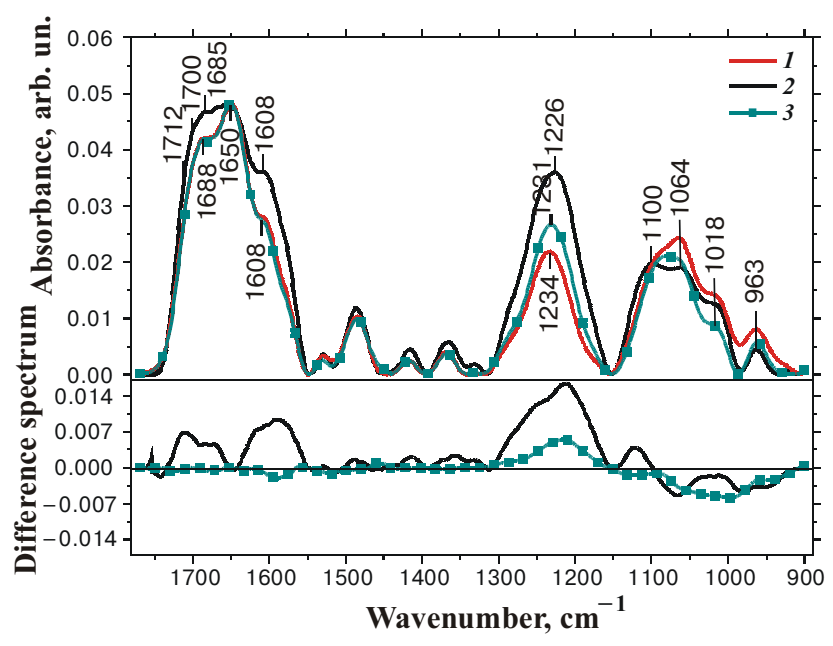

Fig. 4. SEIRA spectrum of denaturated DNA (curve 1), DNA with carbon nanotubes (curve 2) and DNA with ultradispersed graphite (curve 3 ) on the gold substrate in the region $900-1800 \mathrm{~cm}^{-1}$. Difference spectrum $=$ DNA with carbon nanotubes or with graphite - denaturated DNA.

tion equals to $1234 \mathrm{~cm}^{-1}$, in DNA-graphite $-1231 \mathrm{~cm}^{-1}$ (A-form), in DNA-SWCNT - $1226 \mathrm{~cm}^{-1}$ (B-form) [8, 9]. Integral intensity was 1.59 for DNA, 2.00 for DNA graphite and 3.05 for DNA-SWCNT. The shoulder of phosphate symmetrical band at $1100 \mathrm{~cm}^{-1}$ has been found in DNA-SWCNT. This shoulder was absent for denaturated DNA and only a small shoulder was registered in DNAgraphite complex. So, we could suppose that SWCNT causes A-B transition in some fragments of DNA sugarphosphate backbone that can be in agreement with model of DNA wrapped around nanotubes (Fig. 6).

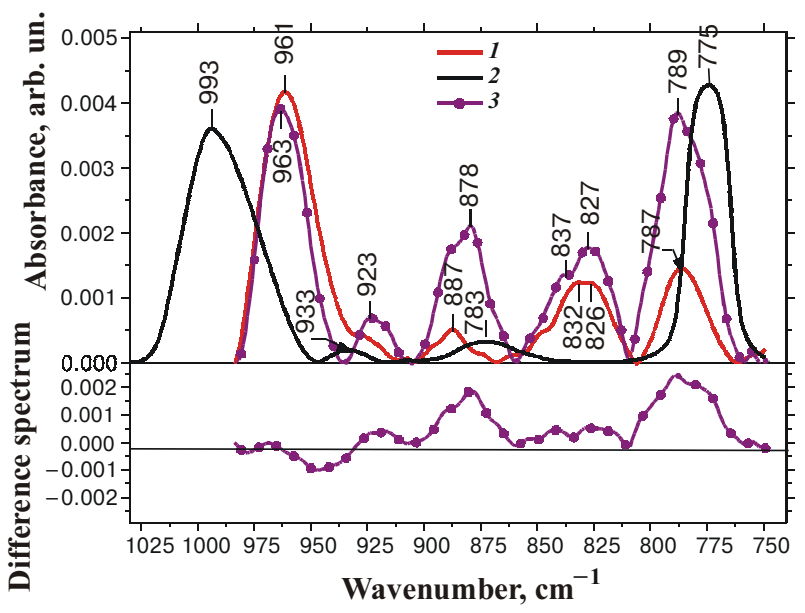

Fig. 5. SEIRA spectrum of denaturated DNA (curve 1), SWCNT (curve 2) and DNA with carbon nanotubes (curve 3) on the gold substrate in the region $740-1030 \mathrm{~cm}^{-1}$. Difference spectrum $=$ DNA with carbon nanotubes - denaturated DNA.

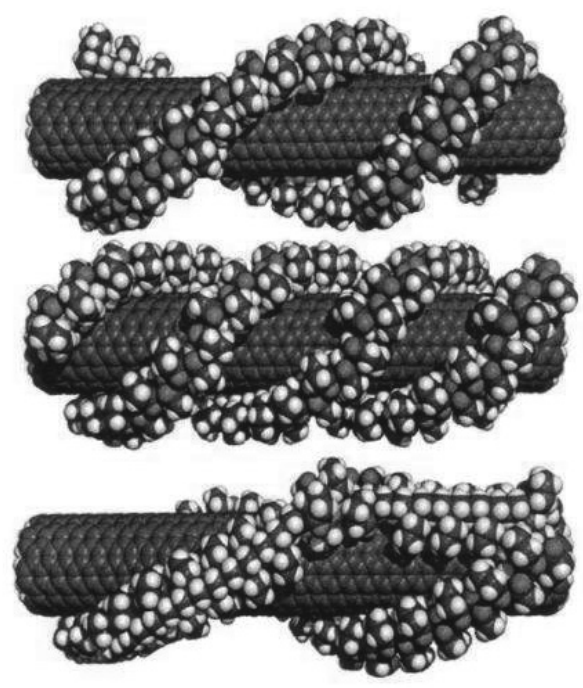

Fig. 6. The model of DNA interaction with carbon nanotubes.

DNA interaction with SWCNT causes to integral intensity increase of the vibrations in the $600-900 \mathrm{~cm}^{-1}$ region(Fig. 5). Thus, the band intensity at $789 \mathrm{~cm}^{-1}\left(787 \mathrm{~cm}^{-1}\right.$ in DNA) is increased by the factor 3.2 ; the band at $827 \mathrm{~cm}^{-1}$ $\left(830 \mathrm{~cm}^{-1}\right.$ in DNA-sugar $\mathrm{C}_{2}$-endo) by 1.4 ; the band at $878 \mathrm{~cm}^{-1}$ $\left(887 \mathrm{~cm}^{-1}\right.$ in DNA-deoxyribose vibration) by 5.5 . The drastic increase of the band at $830 \mathrm{~cm}^{-1}$ indicate to B-form DNA. These drastic changes could be associated with the contribution of the SWCNT absorbtion at 789, 933, $993 \mathrm{~cm}^{-1}$. However, this contribution has non-additive features as we could see from difference spectra [(DNASWCNT complex - DNA)]. The appearance of the band at $923 \mathrm{~cm}^{-1}$ could be assigned to Z-conformation of DNA. The latter fact is indicative of partial presence of $Z$-form helix. 


\section{G.I. Dovbeshko et al.: Study of DNA interaction with carbon nanotubes}

\section{Conclusions}

The analysis of vibration modes of DNA with SWCNT has shown that the structural changes in DNA are observed and could be interpreted as A-B transition and stabilisation of DNA structure in some DNA fragments. Other DNA structural changes connected with unknown conformation states of DNA are simultaneously observed. We registered very slight graphite influence on DNA structure. The obtained data could describe the model of DNA wrapping around SWCNT. The similar situation occurs in chromosomes during DNA assembling by histones.

\section{Acknowledgements}

This work was supported by grant of National Fund for Fundamental Research of Ukraine № 020710004. We are greatly indebted to Prof. Yu.M. Shirshov from the Institute of Semiconductor Physics, NAS of Ukraine for assistance in experiment and Dr M. Westermayer (Frieburg, Germany) for Raman spectra of the samples.

\section{References}

1. Z. Guo, P.J. Sadler, and S.C. Tsang, Immobilization and visualization of DNA and proteins on carbon nanotubes // Adv. Mater. 10, pp. 701 (1998)

2. M.J. O'Connell, P. Boul, L.M. Ericson, C. Huffman, Y. Wang, E. Haroz, C. Kuper, J. Tour, K.D. Ausman, R.E. Smalley,
Reversible water-solubilization of single-walled carbon nanotubes by polymer wrapping // Chem. Phys. Lett. 342, pp. 265-271 (2001).

3. M. In het Panhnis, A. Maiti, I.N. Coleman, A.B. Dalton, B. McCarthy and W.I. Blan. In: Electronic properties of Novel Materials-Molecular Nanostructure (Editored by $\mathrm{H}$. Kuzmany, J. Fink, M. Mehring, S. Roth). Publisher American Institute of Physics Woodbury, Melville, New York. All Conf. Proc. 544, pp. 497-500 (2000).

4. A. Bordyuh, G.I. Dovbeshko, G.V. Andrievsky, V.K. Klochkov, Comparative analysis of two aqueous colloidal solution of C60 fullerene // Phys. Chem (2001) - http:// preprint.chemweb.com/physchem/0107005.

5. G.I. Dovbeshko, V.I. Chegel, N.Y. Gridina, O.P. Repnytska, Y.M. Shirshov, V.P. Tryndiak, I.M. Todor, G.I. Solyanik, Surface enhanced infrared absorption of nucleic acids from tumour cells: an FTIR reflectance study // Biospectroscopy, 67 (6) pp. 470-487 (2002)

6. G.I. Dovbeshko, V.I. Chegel, N.Y. Gridina, O.P. Repnytska, Y.M. Shirshov, V.P. Tryndiak, I.M. Todor, Surface enhanced infrared absorption of nucleic acids on gold substrate // Semiconductor Physics, Quantum Electronics and Optoelectronics 4(3), pp.202-206 (2001).

7. Y. Chen, R.C. Haddon, S. Fang, A.M. Rao, and P.C. Eklund, W.H. Lee, E.C. Dickey, E.A. Grulke, J.C. Pendergrass, A. Chavan, B.E. Haley, R.E. Smalley. Chemical attachment of organic functional groups to single-walled carbon nanotube matirial // Materials Research Society 13(9), pp. 2423-2431 (1998).

8. B. Schrader, Infrared and Raman Spectroscopy. Methods and Applications. Weinheim, New York-Basel-CambridgeTokyo, pp.765 (1995).

9. J. Liquier, A. Akhebat, E. Taillandier, F. Ceolin, T. Huynh Dinh, J. Igolen, Characterization by FTIR spectroscopy of the oligoribonucleotide duplexes $\mathrm{r}(\mathrm{A}-\mathrm{U})_{6}$ and $\left.\mathrm{r}(\mathrm{A}-\mathrm{U})_{8}\right) / /$ Spectrochimica Acta A. 47, pp.177-186 (1991). 